University of Nebraska - Lincoln

DigitalCommons@University of Nebraska - Lincoln

$12-2004$

\title{
Abomasal Parasites in Wild Sympatric Cervids, Red Deer, Cervus elaphus, and Fallow Deer, Dama dama, from Three Localities across Central and Western Spain: Relationship to Host Density and Park Management
}

\author{
Mónica Santín-Durán \\ United States Department of Agriculture \\ José M. Alunda \\ Universidad Complutense de Madrid \\ Eric P. Hoberg \\ United States Department of Agriculture, eric.hoberg@ars.usda.gov \\ Concepción de la Fuente \\ Universidad Complutense de Madrid, cfuente2@vet.ucm.es
}

Follow this and additional works at: https://digitalcommons.unl.edu/parasitologyfacpubs

Part of the Parasitology Commons

Santín-Durán, Mónica; Alunda, José M.; Hoberg, Eric P.; and de la Fuente, Concepción, "Abomasal Parasites in Wild Sympatric Cervids, Red Deer, Cervus elaphus, and Fallow Deer, Dama dama, from Three Localities across Central and Western Spain: Relationship to Host Density and Park Management" (2004). Faculty Publications from the Harold W. Manter Laboratory of Parasitology. 325.

https://digitalcommons.unl.edu/parasitologyfacpubs/325

This Article is brought to you for free and open access by the Parasitology, Harold W. Manter Laboratory of at DigitalCommons@University of Nebraska - Lincoln. It has been accepted for inclusion in Faculty Publications from the Harold W. Manter Laboratory of Parasitology by an authorized administrator of DigitalCommons@University of Nebraska - Lincoln. 


\title{
ABOMASAL PARASITES IN WILD SYMPATRIC CERVIDS, RED DEER, CERVUS ELAPHUS AND FALLOW DEER, DAMA DAMA, FROM THREE LOCALITIES ACROSS CENTRAL AND WESTERN SPAIN: RELATIONSHIP TO HOST DENSITY AND PARK MANAGEMENT
}

\author{
Mónica Santín-Durán*, José M. Alunda, Eric P. Hoberg†, and Concepción de la Fuenteł \\ Departamento de Sanidad Animal, Facultad de Veterinaria, Universidad Complutense de Madrid, Madrid 28040, Spain. e-mail: \\ cfuente2@vet.ucm.es
}

\begin{abstract}
A survey of abomasal parasites in cervids from Central Spain was conducted at 3 sites, Quintos de Mora (Toledo), Maluéñez de Arriba (Cáceres), and La Herguijuela (Cáceres). Commonly occurring helminths belonged to 3 polymorphic species of the Ostertagiinae: Spiculopteragia asymmetrica/S. quadrispiculata, Ostertagia leptospicularis/O. kolchida, and $O$. drozdzi/O. ryjikovi. Trichostrongylus axei was found in very few cases. Ostertagia drozdzilO. ryjikovi and the minor male morphotype, $S$. quadrispiculata, are reported for the first time in red deer from Spain. The 3 ostertagiine species are also reported for the first time in fallow deer from Spain. These 3 species of Ostertagiinae are primarily parasites of cervids, and nematode species characteristic of domestic ruminants were not present. Prevalence of infection by gastrointestinal parasites in cervids was high, ranging from 97.5 to $100 \%$, across the 3 areas sampled. Mean intensity of infection and abundance showed a positive relationship to the population density of red deer. Helminth burdens were higher in fallow deer than in the sympatric red deer and may reflect the gregarious social structure and different foraging patterns of fallow deer.
\end{abstract}

Red deer (Cervus elaphus) are the most abundant and widely distributed cervids in Spain, and during recent years, the populations of this cervid have increased (Tellería and Sáez-Royuela, 1984). Expanding populations can likely be attributed to increasing habitat availability with the concurrent and progressive abandonment of many rural settlements, a growing concern with the conservation of wildlife resources, and the use of management practices that include the alternative for exploitation of free range for domestic livestock. In this regime of ecological transition, protocols for parasitological survey and inventory were used to contribute to a definitive knowledge of helminth biodiversity in cervids from Spain (e.g., Santín-Durán et al., 2001, 2002). A need for basic biodiversity information is the main reason for addressing such timely issues as the influence of management and farming practices for wild and semidomestic ruminants (Dróżdż et al., 1997), interfaces or sympatry for wild species or wild and domestic species (Dróżdż et al., 1992, 2002), and ecological disruption linked to global climate change or anthropogenic factors on the epizootiology and distribution of helminths and other parasites (Daszak et al., 2000; Hoberg et al., 2001, 2003).

Gastrointestinal nematodes are common parasites in wild cervids, and faunal diversity has been reported or described for many European countries (e.g., Hernández et al., 1980; Barth and Matzke, 1984; Batty et al., 1987; Govorka et al., 1988; Dróżdż et al., 1992, 1997; Ambrosi et al., 1993; Rossi et al., 1997; Zaffaroni et al., 1997). These studies have generally confirmed that the dominant parasites of the abomasal nematode fauna in red deer are represented by species of the Ostertagiinae (Dróżdż, 1966, 1967).

Although ostertagiines constitute the core abomasal fauna for cervids, in many cases, the concept of dimorphism or polymorphism among males of respective species in Ostertagia,

Received 31 December 2003; revised 12 April 2004; accepted 12 April 2004.

* Present address: Environmental Microbial Safety Laboratory, USDA, ARS, BARC-East, Building 173, Beltsville, Maryland 20705.

$\dagger$ U.S. National Parasite Collection, and Animal Parasitic Diseases Laboratory, USDA, ARS, BARC-East, Building 1180, Beltsville, Maryland 20705.

$\ddagger$ To whom correspondence should be addressed.
Spiculopteragia, and other genera has often been ignored in the context of either reporting or interpreting the results of survey and inventory (Hoberg et al., 2001). Thus, the "major" and "minor" morphotypes characteristic of single species of ostertagiines (concepts summarized in Dróżdż, 1995) are still commonly reported as discrete species, often in different genera (e.g., Zaffaroni et al., 1997). Such issues highlight the critical importance of correct identification and taxonomy. In addition, given the increasing habitat use by a sylvatic fauna along the boundaries and at the interface of natural and agricultural lands and sympatry with domestic animals, there is a growing concern about the possible role of the wild cervids as reservoirs for infectious and parasitic diseases in domestic livestock.

In this study, we present the results of survey and inventory for abomasal parasites in 2 species of wild cervids (red deer and fallow deer, Dama dama) at 3 localities in central (Quintos de Mora, Toledo) and western Spain (Maluéñez de Arriba and La Herguijuela, Cáceres); collections at Quintos de Mora followed a complete annual cycle. A comparative framework for this study emphasizes the different management conditions (wild fauna exclusively in Quintos de Mora vs. extensive grazing of wild and domestic fauna in 2 localities in Cáceres) and practices for land use (conservation vs. hunting) as potential determinants of the parasite fauna of red and fallow deer.

\section{MATERIALS AND METHODS}

\section{Study areas}

Quintos de Mora (Toledo) (Fig. 1): The study area comprised a government-owned and -managed park of 6,864 ha (Quintos de Mora, Toledo) located in Central Spain $\left(39^{\circ} 25^{\prime} \mathrm{N}, 4^{\circ} 04^{\prime} \mathrm{W}\right)$. The park exhibits considerable habitat heterogeneity and is partitioned into 2 main areas including a plain, $800 \mathrm{~m}$ above sea level (asl) crossed by the Navas River and a surrounding mountainous region with a maximum elevation of $1,235 \mathrm{~m}$ asl. The climate is Mediterranean, with a dry season from June to September (rainfall ca. $14 \mathrm{~mm}$; temperature ca. $24 \mathrm{C}$ ) and a wet season with maximum rainfall in winter and spring (rainfall ca. 33 $\mathrm{mm}$; temperature ca. $10 \mathrm{C}$ ). Vegetation includes an overstory with Pinus pinea, $P$. pinaster, Quercus rotundifolia, and $Q$. faginea as the predominant trees and a shrub-based understory including Arbutus unedo, Phillyrea angustifolia, Cistus ladanifer, and Erica spp. in varying stages of succession (Álvarez et al., 1991). Several species of large wild mammals are found within the park boundaries, including red deer, fallow deer, roe deer (Capreolus capreolus), mufflon (Ovis musimon), and wild boar (Sus scrofa). Red and fallow deer are by far the most abundant, 


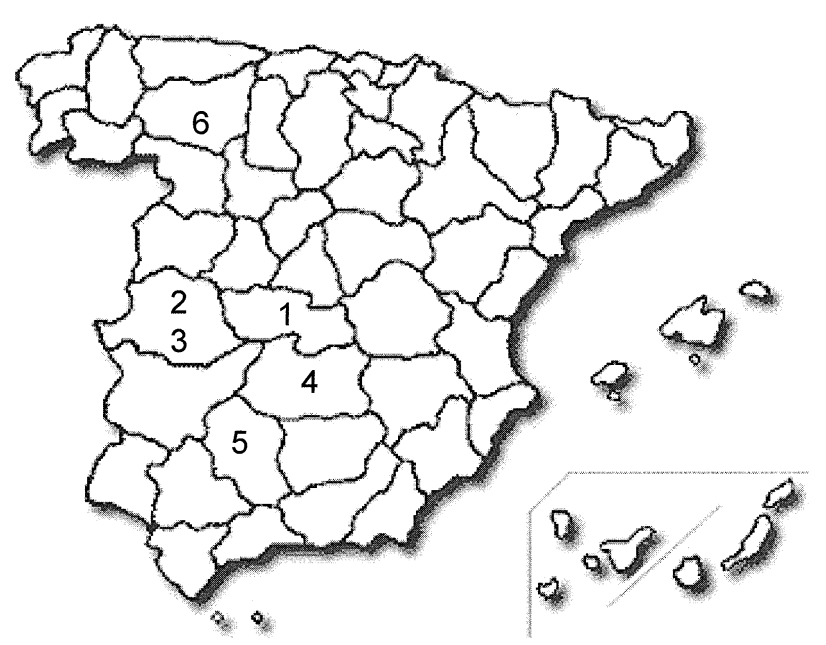

FIGURE 1. Map of Spain showing the locality of the 3 areas studied (1, Quintos de Mora; 2, Maluéñez de Arriba; 3, La Herguijuela) and other areas of Spain in which deer studies have been conducted by García-Romero et al. (2000) (4), Hernández et al. (1980) (5) and Rojo Vázquez and Cordero del Campillo (1975) (6).

with populations of $C$. elaphus estimated at approximately 2,100 individuals (density $=0.3 \mathrm{deer} / \mathrm{ha}$ ), and about 200 fallow deer $(0.03$ deer/ ha) (Álvarez, 1988). Populations of all ungulates are essentially wild, and treatment with anthelmintics or other veterinary health measures have not been undertaken. There is no domestic animal in this area, and the population of cervids is isolated by a continuous wall surrounding the entire park.

Maluéñez de Arriba (Cáceres): Maluéñez de Arriba is a private hunting area of 1,305 ha located in western Spain (Cáceres) $\left(39^{\circ} 50^{\prime} \mathrm{N}\right.$, $05^{\circ} 59^{\prime} \mathrm{W}$ ). The park has 2 parts: a plain and a mountainous area. Vegetation includes $Q$. rotundifolia and $Q$. suber as the predominant trees, and some shrub species, i.e., A. unedo, P. angustifolia, and Erica spp. There is a resident population of C. elaphus of about 800 individuals ( 0.6 deer/ha). In this area, cattle (Bos taurus) have been sharing pastures with wild ruminants (400 females and 150 males, plus the young fawns of the year) for several years.

La Herguijuela (Cáceres): La Herguijuela is also a private hunting area on 2,402 ha located in western Spain (Cáceres) $\left(39^{\circ} 51^{\prime} \mathrm{N}, 5^{\circ} 55^{\prime} \mathrm{W}\right)$. Terrain at this site is comparable with that of Maluéñez (see above); accordingly, vegetation is also very similar. In this area, the population of red deer is approximately 424 individuals $(0.1 \mathrm{deer} / \mathrm{ha})$; deer share common pastures with cattle and sheep (Ovis aries).

\section{Animals studied}

At Quintos de Mora (Toledo), a total of 147 red deer and 17 fallow deer were collected and examined for parasites. Collections were made on a monthly basis during an annual cycle extending from October 1994 to September 1995. Three age groups were considered $(<1 \mathrm{yr}, 1-2 \mathrm{yr}$, adult deer). During each month, at least 3 animals per age group and sex (only in adult deer) were sampled. This study reports analyses of parasites in 81 adult red deer ( 39 males and 42 females) and 16 male fallow deer. Results of collections from other age classes will be considered in subsequent analyses that focus on the annual cycle.

At Cáceres, 52 adult red deer (22 males and 30 females) were collected from Maluéñez de Arriba, and 13 adult male red deer were collected from La Herguijuela during the hunting season (fall 1999).

\section{Necropsy procedures}

All animals were subjected to standard necropsy procedures. Each abomasum was ligated in situ from the small intestine and omasum, removed, and processed for recovery and enumeration of adult nematodes (MAFF, 1971). Abomasal contents and washes were combined and aliquoted, with $2 \times 10 \%$ duplicate aliquots being collected and preserved in ethanol $(70 \%)$ or fixed in phosphate-buffered formalin (5\%). Abomasal digestion for recognition of possible populations of arrested fourth-stage larvae for respective species of ostertagiines was not conducted. The total number of worms of each species was calculated by identifying and counting male and female worms in a $10 \%$ aliquot of the contents from each animal.

\section{Identification of nematodes}

Specimens were studied as temporary whole mounts cleared in phenol-alcohol (80 parts melted phenol crystals and 20 parts absolute ethanol) and examined with interference contrast light microscopy. Male specimens were identified according to Dróżdż (1965), Jančev (1979), Lichtenfels et al. (1988), and Hoberg et al. (1993). Female specimens of Ostertagiinae were identified on the basis of the structure of the synlophe and the esophagus (e.g., Lichtenfels and Hoberg, 1993; M. Santín-Durán, E. P. Hoberg, and A. Abrams, unpubl.). Concepts for polymorphism among species in the Ostertagiinae were adopted following Lancaster and Hong (1981), Lichtenfels and Hoberg (1993), and Dróżdż (1995), and counts of major and minor morphotypes for males of respective species were combined for calculations of intensity and abundance. Although a consistent convention for the taxonomy of dimorphic and polymorphic ostertagiines remains to be articulated (Hoberg et al., 1999), taxonomy in this study follows the structure in which the major morphotype is listed first followed by the minor; e.g., $O$. drozdzi/O. ryjikovi. Representative specimens of these nematodes were deposited in the U.S. National Parasite Collection (from C. elaphus: USNPC 91176, 91274, 91275, 91278, 91279, 91285, 91286, 91290, 91291, 91294, 91297, 91301-91304, 91308-91310, 91313, 91314, $91321,91435,91436,91439-91441,91444,91445,91447,91448$, 91450-91453, 91455, 91458, 91459, 91462, 91463, 91466, 91468, 91470-91472, 91475, 91476, 91480-91482, 91485-91487, 91491, 91493-91496, 91500, 91501; from D. dama: USNPC 93566-93583) at the Animal Parasitic Diseases Laboratory, USDA, ARS Beltsville, Maryland, and in the Departamento de Sanidad Animal, Facultad de Veterinaria, Universidad Complutense de Madrid (UCM), Madrid, Spain.

\section{Data and statistical analyses}

The prevalence, abundance, and mean intensity were calculated as specified in Margolis et al. (1982). The frequency of each species, i.e., (number of nematodes, males and females, of 1 species/total number of nematodes of all species) $\times 100$, was established for each animal on the basis of all the worms found in the aliquot; a mean frequency was calculated from all deer infected. In the same manner, the ratio of major: minor morphotype for the pair of males representing each species of ostertagiine and the percentage of females of each species were calculated.

Data were analyzed at the UCM Computing Center (CPD) using BMDP Statistical Software (Dixon, 1993). Statistics included parametric (Student's $t$-test, analysis of variance) and nonparametric tests (correlation, $\mathrm{X}^{2}$ ). Welch test (alternative $t$ test) was used to compare means when standard deviations were not equal between compared groups. Duncan and Tukey multiple comparison tests were performed when the $P$ value was less than 0.05 . The term significant refers to statistical significance at $P \leq 0.05$.

\section{RESULTS}

\section{Red deer}

Quintos de Mora: Adult nematodes were found in the majority of abomasa examined $(97.5 \%)$, with an overall abundance of $545.8 \pm 549.97$ nematodes/deer and a mean intensity of $559.62 \pm 457.34$ nematodes/deer infected. No sex-related differences were observed in prevalence (males: 97.4\%; females: 97.6\%), abundance (males: 600.51 \pm 490.14; females: $495 \pm$ 429.73), or mean intensity (males: $616.31 \pm 486.55$; females: $507.07 \pm 427.8)$.

Nematodes belonged to 4 species, i.e., Spiculopteragia asymmetrica/S. quadrispiculata, O. leptospicularis/O. kolchida, O. drozdzi/O. ryjikovi, and Trichostrongylus axei. Whereas Ostertagiinae were prevalent and abundant, $T$. axei was found only 
TABLE I. Average percentage ( \pm SD) that different Ostertagiinae represented for the total abomasal worm burdens in infected adult red deer from Quintos de Mora.

\begin{tabular}{lccc}
\hline & $\begin{array}{c}\text { Spiculopteragia } \\
\text { asymmetrical } \\
\text { S. quadrispiculata }\end{array}$ & $\begin{array}{c}\text { Ostertagia leptospicularis/ } \\
\text { O. kolchida }\end{array}$ & $\begin{array}{c}\text { O. drozdzi/ } \\
\text { O. ryjikovi }\end{array}$ \\
\hline Males (38)* & $88.74 \pm 12.45$ & $9.53 \pm 11.99$ & $1.73 \pm 3.07$ \\
Females (41) & $89.68 \pm 18.01$ & $9.02 \pm 16.98$ & $1.29 \pm 3.36$ \\
Total (79) & $89.23 \pm 15.5$ & $9.27 \pm 14.7$ & $1.51 \pm 3.21$ \\
\hline
\end{tabular}

* In parentheses, number of animals sampled.

in 2 red deer. Spiculopteragia asymmetrica/S. quadrispiculata was the most frequent species found in red deer (Table I). Ostertagia leptospicularis/O. kolchida and O. drozdzi/O. ryjikovi occurred at lower percentages. No sex-related difference was observed in the average percentage of ostertagiines in the infected deer. Spiculopteragia asymmetrica/S. quadrispiculata was the most prevalent and abundant species (Table II). The high standard deviation is indicative of an overdispersed distribution pattern. Ostertagia leptospicularis/O. kolchida was present in 55 of $81(67.9 \%)$ red deer, and the prevalence, abundance, and mean intensity were greater in male than in female hosts, but differences were not statistically significant. Ostertagia drozdzi/O. ryjikovi was present in 27 of 81 (33.3\%) deer.

The percentage that represented the $S$. asymmetrica morphotype, in the pair of males constituted by $S$. asymmetrica/S. quadrispiculata, was $82.98 \pm 16.16 \%$ in 76 infected adult deer. We did not find significant differences in percentage constituted by the $S$. asymmetrica morphotype in male versus female hosts (males: $85.69 \pm 12.04$; females: $80.4 \pm 19.08$ ). The O. leptospicularis morphotype was dominant $(99.52 \pm 2.57 \%)$ in the dimorphic species represented by $O$. leptospicularis/O. kolchida. Ostertagia drozdzi was the predominant morphotype with an average percentage of $72.22 \pm 37.92 \%$ in the pair of males that constitute the dimorphic species $O$. drozdzi/O. ryjikovi; no significant difference was found related to the sex of the hosts.

Maluéñez de Arriba: Adult nematodes were found in the majority of abomasa examined (98.08\%), with an overall abundance of $895 \pm 867.51$ nematodes/deer and a mean intensity of $912.55 \pm 866.79$ nematodes/deer infected. Four species were identified: S. asymmetrica/S. quadrispiculata, O. leptospicularis/O. kolchida, O. drozdzi/O. ryjikovi, and T. axei (Table III).
Prevalence of infection with abomasal nematodes was very high; S. asymmetrica/S. quadrispiculata was the most common species in both sexes. However, the prevalence of $O$. leptospicularis/O. kolchida in male hosts was significantly higher than in females $(P=0.0001)$. Ostertagia drozdzi/O. ryjikovi was not present in female red deer and was seldom found in males (18\%). Also, a low prevalence was observed for $T$. axei in males and females (ca. 17\%).

Abundance and mean intensity of abomasal infection, including all species and for $S$. asymmetrica/S. quadrispiculata, differed significantly between male and female red deer (Table III). For O. leptospicularis/O. kolchida, the differences were only significant for abundance $(P=0.0011)$ when male and female hosts were compared, but not for intensity. There was no difference in the distribution of $T$. axei between males and females.

In the abomasa of infected red deer, the mean percentages that each species represented were: $S$. asymmetrica/S. quadrispiculata, $91.63 \pm 10.37 ;$ O. leptospicularis/O. kolchida, $6.66 \pm$ 8.96; O. drozdzi/O. ryjikovi, $0.08 \pm 0.30$; and T. axei, $1.54 \pm$ 5.20. The mean percentage of $S$. asymmetrica/S. quadrispiculata was significantly greater in females $(94.77 \pm 9.5$ in females vs. $87.50 \pm 10.47$ in males $)(P=0.0126)$, whereas the opposite was observed for $O$. leptospicularis/O. kolchida $(10.26 \pm 8.81$ in males vs. $3.93 \pm 8.37$ in females $)(P=0.0119)$.

In the species of ostertagiines, the relative abundance for major morphotypes represented in the total for males of each species was similar to that observed at other sites: $S$. asymmetrical S. quadrispiculata $(\mathrm{n}=50) 84.46 \pm 9.79 \%$, O. leptospicularis/ O. kolchida $(\mathrm{n}=26) 89.35 \pm 21.80 \%$, and $100 \%$ for $O$. drozdzilO. ryjikovi $(\mathrm{n}=3)$. In female red deer, we found a

TABLE II. Prevalence $(\%)$, abundance $( \pm \mathrm{SD})$, and mean intensity $( \pm \mathrm{SD})$ of Ostertagiinae in adult red deer from Quintos de Mora.

\begin{tabular}{|c|c|c|c|c|c|}
\hline & & $\begin{array}{c}\text { No. of } \\
\text { animals } \\
\text { parasitized }\end{array}$ & Prevalence & $\begin{array}{l}\text { Abundance } \\
( \pm \mathrm{SD})\end{array}$ & $\begin{array}{c}\text { Mean } \\
\text { intensity } \\
( \pm S D)\end{array}$ \\
\hline \multirow[t]{3}{*}{ Spiculopteragia asymmetrica/S. quadrispiculata } & Males & 38 & 97.4 & $528.7 \pm 437.3$ & $542.6 \pm 434.4$ \\
\hline & Females & 40 & 95.2 & $440.7 \pm 366.4$ & $462.7 \pm 361.5$ \\
\hline & Total & 78 & 96.3 & $483.1 \pm 402$ & $501.7 \pm 398.1$ \\
\hline \multirow[t]{3}{*}{ Ostertagia leptospicularis/O. kolchida } & Males & 28 & 71.8 & $58.7 \pm 88.7$ & $81.8 \pm 95.5$ \\
\hline & Females & 27 & 64.3 & $46.7 \pm 97.9$ & $72.6 \pm 114.7$ \\
\hline & Total & 55 & 67.9 & $52.5 \pm 93.2$ & $77.3 \pm 104.5$ \\
\hline \multirow[t]{3}{*}{ O. drozdzi/O. ryjikovi } & Males & 15 & 38.5 & $13.1 \pm 23.5$ & $34 \pm 27.2$ \\
\hline & Females & 12 & 28.6 & $7.6 \pm 19.5$ & $26.7 \pm 29.3$ \\
\hline & Total & 27 & 33.3 & $10.2 \pm 21.6$ & $30.7 \pm 27.9$ \\
\hline
\end{tabular}


TABLE III. Prevalence $(\%)$, abundance $( \pm \mathrm{SD})$, and mean intensity $( \pm \mathrm{SD})$ of the species found in abomasa of male and female red deer from Maluéñez de Arriba.

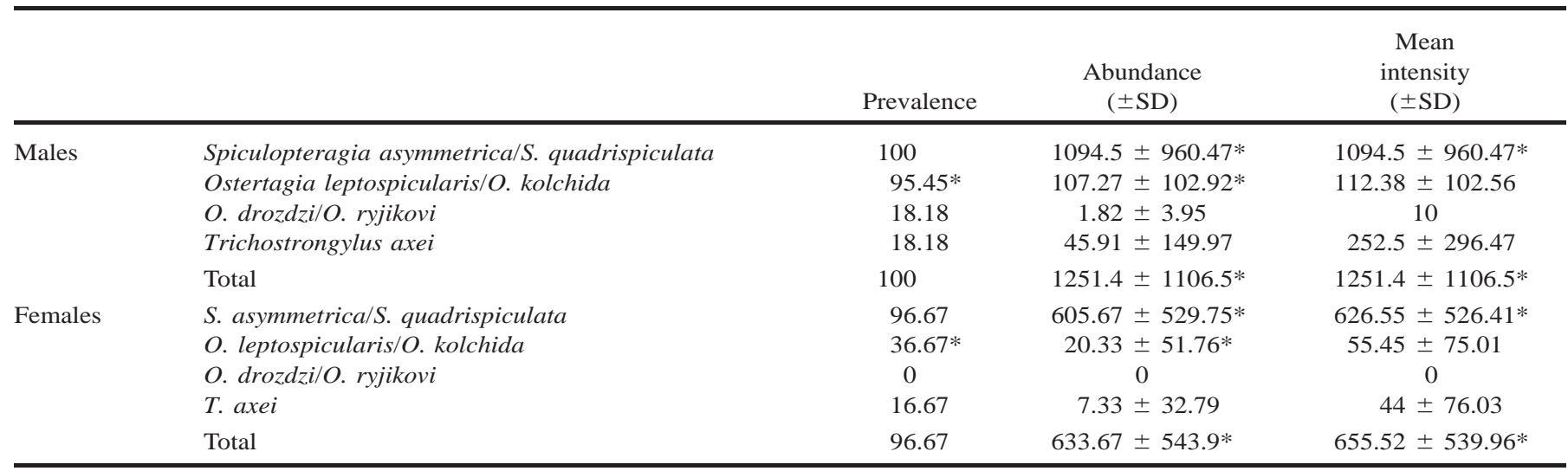

* Significant differences between sexes $(P \leq 0.05)$.

significantly higher percentage of the $S$. asymmetrica morphotype $(87.64 \pm 9.20$ in females vs. $80.41 \pm 9.43$ in males $)(P$ $=0.0089)$ and of the $O$. leptospicularis morphotype (98.52 \pm 4.44 in females vs. $84.49 \pm 26.27$ in males $)(P=0.0467)$. The percentages of female nematodes found in each species were: $59.03 \pm 14.95$ for $S$. asymmetrica/S. quadrispiculata $(\mathrm{n}=51)$; $58.26 \pm 30.52$ for O. leptospicularis/O. kolchida $(\mathrm{n}=32)$; and $84.58 \pm 16.49$ for $T$. axei $(\mathrm{n}=7)$. No difference was observed in the percentages of female nematodes of any nematode species when occurrence linked to sex of host was compared.

La Herguijuela: Nematodes were found in the abomasa of all red deer examined $(\mathrm{n}=13)$ at this site. Overall, mean intensity was $226.15 \pm 209.45$ abomasal nematodes per host, ranging from 20 to 740. Spiculopteragia asymmetrica/S. quadrispiculata was the most common species (100\%), with a mean intensity of $225.38 \pm 209.93$ nematodes per infected host. Ostertagia leptospicularis/O. kolchida was only present in 1 of 13 abomasa examined $(7.69 \%)$, and its intensity (10 nematodes) was very low.

Spiculopteragia asymmetrica/S. quadrispiculata represented a percentage of $99.23 \pm 2.66$ in abomasa of infected animals, whereas $O$. leptospicularis/O. kolchida was $0.77 \pm 2.66$. In red deer infected with males of $S$. asymmetrica/S. quadrispiculata, the major morphotype occurred at $85.70 \% \pm 15.64(\mathrm{n}=12)$. In the only 2 red deer infected by $O$. leptospicularis/O. kolchi$d a$, the minor morphotype $O$. kolchida was not found. Females of $S$. asymmetrica/S. quadrispiculata $(\mathrm{n}=13)$ represented a percentage of $66.68 \pm 8.18$ and for $O$. leptospicularis/O. kolchida $(\mathrm{n}=2) 66.67 \%$ of the population for each species.

\section{Comparison of collection sites}

A comparison, considering data from red deer for the 3 study areas, is shown in Table IV. Prevalence of infection for abomasal nematodes exhibited no difference across the 3 sites. In contrast, mean intensity of infection was significantly higher in Maluéñez de Arriba than in the other areas; Quintos de Mora and La Herguijuela did not differ. Three species of ostertagiines were represented, but all species were not present at each site; $T$. axe $i$ was sporadic in its occurrence.

Some differences in the specific composition of the infections were evident because at La Herguijuela only 2 species, $S$. asymmetrica/S. quadrispiculata and O. leptospicularis/O. kolchida, were identified. The prevalence of O. leptospicularis/O. kolchida was significantly lower in red deer at La Herguijuela than in the other 2 parks. Ostertagia drozdzi/O. ryjikovi was significantly more prevalent at Quintos de Mora than at Maluéñez de Arriba. In contrast, for $T$. axei we found significantly lower prevalence at Quintos de Mora than at Maluéñez de Arriba ( $P$ $=0.0001$ ).

Significant differences were found in the intensity of infection for $S$. asymmetrica/S. quadrispiculata among red deer from the 3 areas studied $(P<0.001)$. The intensity of infection for O. leptospicularis/O. kolchida was greater at Maluéñez de Arriba than at Quintos de Mora and La Herguijuela and that from O. drozdzi/O. ryjikovi was greater, but not significantly so, at Quintos de Mora than at Maluéñez de Arriba. Trichostrongylus axei only occurred with a moderate mean intensity at Maluéñez de Arriba, and it was found sporadically in Quintos de Mora. There were significant differences in the percentage of $S$. asymmetrica/S. quadrispiculata in abomasa of red deer among areas studied $(P<0.01)$, and $O$. drozdzi/O. ryjikovi showed a lower percentage in Maluéñez de Arriba $(P=0.0001)$.

Considering the relative abundance of male morphotypes within respective species of ostertagiines, few differences were noted. The percentage of $S$. asymmetrica morphotype did not show differences among areas studied. However, the O. leptospicularis morphotype was more prevalent in hosts from Quintos de Mora than from Maluéñez de Arriba (98.64 \pm 7.93 vs. $89.35 \pm 21.80)(P=0.0425)$. The minor morphotype associated with $O$. drozdzi was not found at Maluéñez de Arriba.

\section{Fallow deer}

Sampling of fallow deer occurred at Quintos de Mora where they are sympatric with red deer. Adult nematodes were recovered from 13 of 16 abomasa studied, and prevalence of infection $(81.3 \%)$ did not differ significantly from that found in red deer from the same locality (Tables IV, V). Prevalence of $S$. asymmetrica/S. quadrispiculata was slightly greater in red deer, whereas fallow deer showed a higher, although not significantly different, prevalence of $O$. drozdzi/O. ryjikovi. However, prev- 


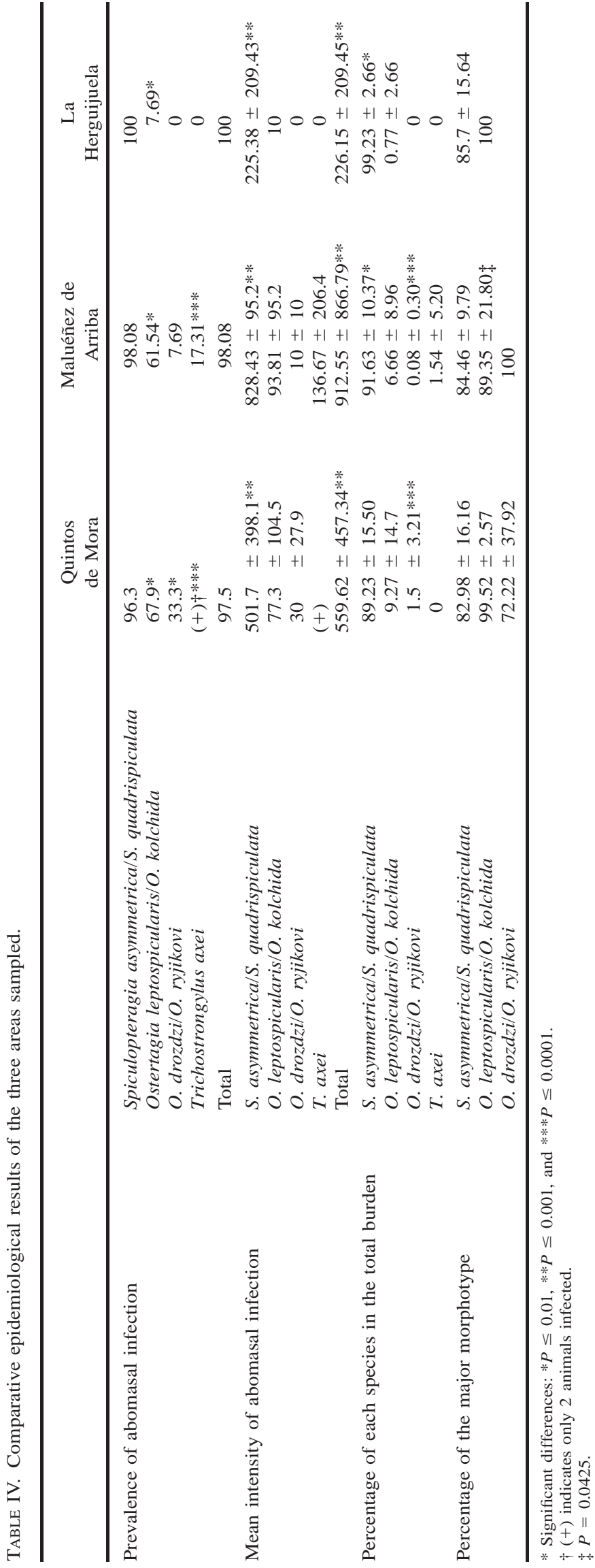

alence of $O$. leptospicularis/O. kolchida was much greater in red deer $(P=0.00001)$. Abundance $(719.37 \pm 611.83$ nematodes/deer) and intensity $(885.38 \pm 555.6$ nematodes/deer infected) of abomasal infection were higher in fallow than red deer $(P<0.05)$. Fallow deer were significantly more heavily infected with $S$. asymmetrica/S. quadrispiculata and $O$. drozdzil $O$. ryjikovi, but red deer had higher abundance and mean intensity of $O$. leptospicularis/O. kolchida $(P<0.05)$.

Considering these sympatric cervids, $S$. asymmetrica/S. quadrispiculata represented the dominant ostertagiines. However, the percentage of $O$. leptospicularis/O. kolchida found in red deer was higher than in fallow deer $(9.27 \pm 14.70$ vs. 0.35 $\pm 1.09)(P=0.0001)$. The opposite was observed for $O$. dro$z d z i / O$. ryjikovi in which there was a larger percentage in fallow deer than in red deer $(9.05 \pm 10.97$ vs. $1.51 \pm 3.21)$.

There was no significant difference in the percentage represented by the major morphotypes for $S$. asymmetrica/S. quadrispiculata and $O$. drozdzi/O. ryjikovi $(P>0.05)$. However, we observed that these percentages were always higher in fallow deer than in red deer. Fallow deer also harbored larger relative populations of females of $S$. asymmetrica/S. quadrispiculata and $O$. drozdzi/O. ryjikovi than red deer.

\section{DISCUSSION}

\section{Species diversity}

Multispecies assemblages of ostertagiine nematodes are the rule in cervids, consistent with observations from our study. Most species of abomasal nematodes recovered in this study have been reported previously in red deer from Spain. S. asymmetrica/S. quadrispiculata has been observed in red and roe deer, O. leptospicularis/O. kolchida only in red deer, and T. axei has been found in a wide range of hosts, including red deer (Cordero del Campillo et al., 1994; Ortiz et al., 1996; GarcíaRomero et al., 2000). However, this is the first report in Spain for $O$. drozdzi/O. ryjikovi, but it has been reported in red deer from other European countries (Jančev, 1979; Ambrosi et al., 1993; Rehbein and Haupt, 1994; Dróżdż et al. 1997). Moreover, as far as we know, this is the first study of abomasal nematodes in fallow deer from Spain and, thus, the collection of $S$. asymmetrica/S. quadrispiculata, O. leptospicularis/O. kolchida, and O. drozdzi/O. ryjikovi constitutes new host records for the country.

Very few reports have been published on the relative abundance of major and minor morphotypes for males among species of Ostertagiinae (Dróżdż et al., 1987, 1992; Hoberg et al., 1999), and most observations have been limited to faunas in domestic ruminants. In our case, we found different ratios characteristic for each genus and species of the subfamily, and no variation was observed to be related to the sex of the hosts. The only exception was the apparent increase among older animals in the relative abundance of the minor morphotype for O. drozdzi/O. ryjikovi. Dróżdż et al. (1987) also found an increase of the minor phenotype for $S$. spiculoptera/S. mathevossiani associated with age of host in roe deer but not for $O$. leptospicularis/O. kolchida. In addition, when the ratios for male morphotypes among respective species of ostertagiines in sympatric cervids from Quintos de Mora were compared, a greater percentage of major forms of $S$. asymmetrica/S. quadrispiculata and $O$. drozdzi/O. ryjikovi were found in fallow deer. 
TABle V. Descriptive parameters of the abomasal nematodes from fallow deer in Quintos de Mora.

\begin{tabular}{|c|c|c|c|}
\hline & $\begin{array}{l}\text { Spiculopteragia } \\
\text { asymmetrical } \\
\text { S. quadrispiculata }\end{array}$ & $\begin{array}{l}\text { Ostertagia } \\
\text { leptospicularis/ } \\
\text { O. kolchida }\end{array}$ & $\begin{array}{l}\text { O. drozdzil } \\
\text { O. ryjikovi }\end{array}$ \\
\hline Abundance $\pm \mathrm{SD}$ & $659.37 \pm 566.46$ & $2.5 \pm 7.75$ & $37.5 \pm 78.02$ \\
\hline Mean intensity $\pm \mathrm{SD}$ & $811.53 \pm 517.02 *$ & $20 *$ & $92 \pm 81.35^{*}$ \\
\hline Percentage of each species in the total burden $( \pm S D)$ & $90.6 \pm 11.47$ & $0.35 \pm 1.09^{*}$ & $9.05 \pm 10.97 *$ \\
\hline
\end{tabular}

* Significant differences to the values found in the sympatric red deer.

Perhaps this may be related to fallow deer being the principal cervid host for $S$. asymmetrica/S. quadrispiculata and $O$. drozdzi/O. ryjikovi (Dróżdż, 1995).

There is also evidence that the ratio of major:minor morphotypes may be altered seasonally or through senescence of the entire population in a host; for example, consider Teladorsagia boreoarcticus, where the percentage of the minor morphotype may exceed $50 \%$ of the total population late in the winter (Hoberg et al., 1999; E. Hoberg and S. Kutz, unpubl. data). Host species and age, seasonal effects, and population senescence may serve as determinants in the maintenance of a balanced polymorphism for males among species of some ostertagiines, but the biological significance of this phenomenon remains elusive.

Nematode species identified in this study are typical parasites of cervid hosts (Dróżdż, 1965; Jančev, 1979; Govorka et al., 1988), except for T. axei, a common gastrointestinal nematode of a variety of ruminants, including deer, and some monogastric animals. Although O. leptospicularis/O. kolchida is a typical cervid parasite, it has also been found associated with $O$. ostertagi/O. lyrata in cattle, where it can be a significant pathogen (Dunn, 1983; Hoberg et al., 1993). Ostertagia drozdzi/O. ryjikovi as well as $S$. asymmetrica/S. quadrispiculata are considered typical parasites of fallow deer (Kotrlá and Kotrlý, 1975; Jančev, 1979), and the former has only been reported in other hosts (red deer and goat, Capra hircus) when fallow deer were sympatric and sharing common pasture (Rehbein and Haupt, 1994; Dróżdż et al. 1997).

It is important to emphasize that there was no contact between cervids and domestic ungulates in Quintos de Mora (Toledo), but contact was the usual situation at both Maluéñez de Arriba and La Herguijuela (Cáceres). Even so, no notable difference was observed for faunal diversity among areas, and no species typical of domestic ruminants, except $T$. axei, was found at Maluéñez de Arriba and La Herguijuela. No evidence of parasite switching between cervids and bovids was obtained from our results, in contrast to reports by Lanfranchi et al. (1985) and Batty et al. (1987). The possibility of cross-transmission for gastrointestinal nematodes among domestic and wild ruminants is a controversial issue, and such species typical of domestic ruminants as $O$. ostertagi/O. lyrata, Teladorsagia circumcincta/T. trifurcata/T. davtiani, and Haemonchus contortus have been reported in cervids sharing pastures with cattle, sheep, and goats (Barth and Matzke, 1984; Zaffaroni et al. 1997, 2000). It should be noted that evolving concepts for species diversity and specificity among species of Teladorsagia and Haemonchus may alter our understanding of host associa- tions for abomasal nematodes (Hoberg et al. 1999, 2004; Liegnel et al., 2002).

In our study, we provide only limited evidence for acquisition of gastrointestinal nematodes from domestic hosts as indicated by the occurrence of $T$. axe $i$ in red deer, otherwise, our data are consistent with a level of independence between wild and domestic faunas. Increasingly, however, with the advent of ecological perturbation linked to global environmental change and the breakdown in isolating mechanisms between faunas, heightened levels of reciprocal exchange, dissemination, and emergence may be predicted with unknown outcomes for both domestic and wild ungulates (Hoberg, 1997; Daszak et al., 2000; Hoberg et al., 2001, 2003).

Richer nematode communities have been reported from other areas of Europe, but it could be related to co-occurrence of red deer with other sympatric cervids and bovids and not with domestic ruminants (Dróżdż et al., 1992, 1997). Among studies reporting greater species richness, only 2 or 3 nematodes are responsible for the abomasal infections among cervids, and these are always typical components of fauna restricted to deer (e.g., Dunn, 1965; Rossi et al., 1997; Zaffaroni et al., 1997). Such observations do not reduce the importance of understanding the influence of ecotones or interfaces between managed and natural ecosystems on helminth diversity in cervids and bovids (Hoberg et al., 2001). Notably, translocation and introduction remain as major determinants of parasite faunal diversity. A primary example is seen in the widespread occurrence, host switching, and dissemination of Ashworthius sidemi in western Europe coinciding with the introduction of sika, C. nippon, from Eurasia (Ferté et al., 2000); this haemonchine has yet to be recognized in Spain.

\section{Quantitative faunal comparisons}

It is challenging to directly compare both qualitative and quantitative aspects of our studies with results of previous research because many of these investigations of cervid parasites failed to consider the concept of polymorphism for ostertagiine males. Thus, even in recent literature, respective major and minor morphotypes of single species are referred to different genera or as discrete congeneric species (e.g., Ambrosi et al., 1993; Mason, 1994; Rehbein and Haupt, 1994; García Romero et al., 2000). Such practices continue even when the concept of polymorphism has been clearly demonstrated across the continuum from comparative morphology to multilocus analyses of DNA sequences (Lancaster et al., 1983; Lichtenfels et al., 1988; Andrews and Beveridge, 1990; Hoberg et al., 1993; Dróżdż, 1995; 
Stevenson et al., 1996; Zarlenga et al., 1998; Santín-Durán et al., 2002). This is not a trivial issue because erroneous reports confuse our understanding of host and geographic distributions, epizootiology, and predictions about the behavior of a variety of parasites in different hosts or ecological settings.

Spiculopteragia asymmetrica/S. quadrispiculata was by far the dominant species in red and fallow deer from the 3 areas (more than $80 \%$ of the nematodes found in each abomasum). We did not find S. spiculoptera/S. mathevossiani, which is considered a typical abomasal nematode of red deer and has been previously reported in Spain (Rojo Vázquez and Cordero del Campillo, 1975). Although the latter has been the predominant ostertagiine in red deer from Poland (Dróżdż et al., 1994, 1997) in other regions both species of Spiculopteragia were present at similar levels (Dunn, 1983; Suárez et al., 1991, 1997).

Species found in fallow deer, i.e., S. asymmetrica/S. quadrispiculata, O. leptospicularis/O. kolchida and O. drozdzilO. ryjikovi, were present in red deer and are typical of cervid hosts. Spiculopteragia asymmetrica/S. quadrispiculata had the higher percentage in abomasa of infected animals (as in red deer). However, in fallow deer, the percentage of $O$. drozdzi/O. ryjikovi was greater than in red deer, whereas O. leptospicularis/ O. kolchida occurred sporadically. Our results agree with those of Dróżdż et al. (1997) who also found the 2 species in sympatric cervids, red and fallow deer, but as in this study, with different percentages; S. spiculoptera/S. mathevossiani and $O$. leptospicularis/O. kolchida were predominant species in red deer and S. asymmetrica/S. quadrispiculata and O. drozdzi/O. ryjikovi in fallow deer. Because experimental infections have not been conducted, no information on the reason for these differences is available (physiology, ecology, or immunology), although fallow deer are considered the principal hosts for the latter ostertagiines.

A high prevalence of infection by abomasal nematodes, approaching $100 \%$, has been a common observation in all parasite surveys carried out among cervids, with a mean intensity of infection that is usually considered moderate relative to levels observed among domestic ruminants (Suárez et al., 1991; Dróżdż et al., 1994, 1997; Rossi et al., 1997; García-Romero et al., 2000; Hoberg et al., 2001). Although most deer were infected in this study, abundance and intensity were variable; such may represent variation linked to seasonal effects, which will be examined in a subsequent comparative framework.

An overdispersed pattern was observed for the distribution of all species of ostertagiines in red deer from Quintos de Mora. Thus, although prevalence of infection was near $100 \%$, relatively few hosts harbored infections of great intensity. Aggregation of parasite infrapopulations is the rule rather than the exception (Anderson, 1978, 1982), including those in wild hosts (Grenfell et al., 1995). In addition, this population model is frequently found among parasites with direct life cycles in which infective stages are passively ingested by the host; in this case, while grazing.

There was a direct relationship between host density and parasite burdens in red deer. Greatest intensity of infection for abomasal nematodes occurred at Maluéñez de Arriba (0.6 red deer/ha), whereas the lowest helminth burdens were documented at La Herguijuela (0.1 red deer/ha). Differences among sites were also observed when collection data were corrected for the season of collection at respective localities. In this instance, comparisons were solely on the basis of hosts sampled in the same period of the annual cycle (fall), and at Quintos de Mora during this season, abundance and mean intensity were 463 nematodes/deer. These empirical data are consistent with theoretical predictions about the positive linkage of host density with the intensity infection and abundance of parasites (Anderson and May, 1978; Arneberg et al., 1998). Dróżdż et al. (1994) observed peak levels of intensity of infection for abomasal nematodes before culling of an expanding population of red deer in Poland. Suárez et al. (1997) noted higher parasite burdens in farmed deer maintained at high densities compared with wild populations. In addition, Eve and Kellogg (1977) have established a correlation between intensity of infection and local population density for hosts in studies of white-tailed deer (Odocoileus virginianus). Such empirical observations are important in establishing an understanding of positive feedbacks between density for hosts and parasites, linkages to habitat structure and stability, and the regulation of populations of wild ungulates (Grenfell, 1992; Arneberg et al., 1998). Currently, there are no data available from boreal systems to demonstrate regulatory effects of parasites on host populations through fecundity or other effects such as those demonstrated for reindeer and ostertagiines at Svalbard in the Arctic (see Albon et al., 2002).

No definite pattern of sex-related parasitism (prevalence and intensity) was demonstrated in this study. Differences between sexes have been described (Bye and Halvorsen, 1983; Barth and Matzke, 1984) and have been attributed to hormone levels usually during breeding (Dobson, 1964; Grossman, 1985; Zuk and McKean, 1996). Male deer are usually more heavily parasitized than the females (Dunn 1965, 1983; Batty et al., 1987; Ambrosi et al., 1993; Poulin, 1996; Rossi et al., 1997), whereas in other reports no evidence of this difference was obtained (Zaffaroni et al., 1997; Halvorsen and Bye, 1999); studies should be examined in the context of seasonal effects and the timing of collections. We found significantly higher burdens in male deer at Maluéñez de Arriba and Quintos de Mora, but the differences were not significant in the latter locality.

The greater parasite burdens found in fallow deer than those from the sympatric red deer in Quintos de Mora could be related to the feeding behavior of the hosts. The former are grazers that depend more on the pastures; in contrast, red deer are primarily browsers, with only $25 \%$ of total food intake being represented by grasses and forbs (Álvarez, 1990). In addition, fallow deer are highly gregarious (Soriguer et al., 1994), which further contrasts with red deer. Interestingly, these results are in sharp contrast to the results obtained by Dróżdż et al. (1997), and the primary difference between the respective studies is that sympatric cervids were farmed and confined and at relatively high densities, rather than wild and completely free ranging.

Overall, the abomasal parasite fauna of both red deer and fallow deer in central and west Spain were characterized by relatively low diversity. There was minimal variation among the 3 sites, and there was no apparent effect related to common grazing for red deer and domestic ungulates including cattle and sheep. However, a concurrent study of the fauna typical in domestic ungulates was not conducted, but it is predicted that for some species such as O. leptospicularis/O. kolchida, cervids could serve as a source of infections for domestic stock in areas of sympatry. Further studies of this cervid fauna will include 
an examination of the seasonal effects on the diversity and distribution of abomasal nematodes. Such a biodiversity survey and inventory serves as a baseline for documenting faunal stability and transition in a regime of global change (e.g., Hoberg et al., 2003).

\section{ACKNOWLEDGMENTS}

We deeply thank Instituto Conservación de la Naturaleza (ICONA) and the Spanish Ministry of Science and Technology (BOS2003-09027$\mathrm{CO}-03$ ) for partial financial support of this project. Cooperation of $\mathrm{J}$. M. Sebastián and C. Rodríguez was critical. Warden services and J. M. San Miguel, I. Domínguez, A. López, A. González, and M. Carballo helped us in the collection of red deer and sampling for parasites. Some laboratory studies by M.S.-D. with E.P.H. were conducted at the U.S. National Parasite Collection, and we wish to thank P. Pilitt and A. Abrams for their assistance in preparation of specimens.

\section{LITERATURE CITED}

Albon, S. D., A. Stein, R. J. Irvine, R. Langvatn, E. Ropstad, And O. Halvorsen. 2002. The role of parasites in the dynamics of a reindeer population. Proceedings of the Royal Society of London, Series B 269: 1625-1632.

Álvarez, G. 1988. Problemas asociados a la aplicación del transecto lineal para el censo de las poblaciones de cérvidos en un biotopo mediterráneo (Quintos de Mora, Montes de Toledo). Ecología 2: 233-249.

- 1990. El uso del cereal por las poblaciones de cérvidos (Cervus elaphus, Dama dama, Capreolus capreolus) en una finca cinegética mediterránea. Ecología 4: 159-169.

-, T. Martínez, AND E. MarTínez. 1991. Winter diet of red deer stag (Cervus elaphus L.) and its relationship to morphology and habitat in central Spain. Folia Zoologica 40: 117-130.

Ambrosi, M., M. T. Manfredi, and P. Lanfranchi. 1993. Pattern of abomasal helminths in fallow deer farming in Umbria (central Italy). Veterinary Parasitology 47: 81-86.

ANDERSON, R. M. 1978. The regulation of host population growth by parasitic species. Parasitology 76: 119-157.

- 1982. Processes influencing the distribution of parasite numbers within host populations with special emphasis on parasiteinduced host mortalities. Parasitology 85: 373-398.

—, AND R. M. MAY. 1978. Regulation and stability of host-parasite population interactions. I. Regulatory processes. Journal of Animal Ecology 47: 219-247.

Andrews, R. H., AND I. Beveridge. 1990. Apparent absence of genetic differences among species of Teladorsagia (Nematoda: Trichostrongylidae). Journal of Helminthology 64: 290-294.

Arneberg, P., A. Skorping, B. Grenfell, And A. F. Read. 1998. Host densities as determinants of abundance in parasite communities. Proceedings of the Royal Society of London 265: 1283-1289.

BARTH, D., AND P. MATZKE. 1984. Gastro-intestinal nematodes of fallow deer (Dama dama L.) in Germany. Veterinary Parasitology 16: $173-176$.

Batty A. F., D. I. Chapman, and N. Chapman. 1987. Prevalence of nematode parasites in wild fallow deer (Dama dama). The Veterinary Record 120: 599.

Bye, K., And O. Halvorsen. 1983. Abomasal nematodes of the Svalbard reindeer (Rangifer tarandus platyrhynchus vrolik). Journal of Wildlife Diseases 19: 101-105.

Cordero del Campillo, M., L. Castañón-Ordóñez, and A. Reguera FEO. 1994. Índice-catálogo de zooparásitos ibéricos, 2nd ed. Universidad de León, Secretariado de Publicaciones, León, Spain, 650 p.

Daszak, P. A., A. Cunningham, and A. D. Hyatt. 2000. Emerging infectious diseases of wildlife-Threats to biodiversity and human health. Science 287: 443-449.

Dixon, W. P. 1993. BMDP statistical software manual. University of California Press, Berkeley, California, 1,500 p.

Dobson, C. 1964. Host endocrine interactions with nematode infections. I. Effects of sex, gonadectomy, and thyroidectomy on experimental infections in lambs. Experimental Parasitology 15: 200-212.

DRóżDż, J. 1965. Studies on helminths and helminthiases in Cervidae
I. Revision of the subfamily Ostertagiinae Sarwar, 1956 and an attempt to explain the phylogenesis of its representatives. Acta Parasitologica Polonica 13: 445-481.

1966. Studies on helminths and helminthiases in Cervidae II. The helminth fauna of Cervidae in Poland. Acta Parasitologica Polonica 14: 1-13.

- 1967. Studies on helminths and helminthiases in Cervidae III. Historical fomation of helminthofauna in Cervidae. Acta Parasitologica Polonica 14: 287-300.

. 1995. Polymorphism in the Ostertagiinae Lopez-Neyra, 1947 and comments on the systematics of these nematodes. Systematic Parasitology 32: 91-99.

, A. W. Demiaszkiewicz, AND J. Lachowicz. 1992. The helminth fauna of the roe deer Capreolus capreolus (L.) in a hunting area inhabited by red deer, elk and European bison (Borecka Forest, Poland) over the yearly cycle. Acta Parasitologica 37: 83-88.

_ - AND $\longrightarrow$ 1994. The effect of culling red deer, Cervus elaphus (L.), on their helminth fauna in the Slowinski National Park (Poland). Acta Parasitologica 39: 92-94.

, $\longrightarrow$ AND $\longrightarrow$ 2002. Exchange of gastrointestinal nematodes between roe and red deer (Cervidae) and European bison (Bovidae) in the Bieszczady Mountains (Carpathians, Poland). Acta Parasitologica 47: 314-317

- J. Lachowicz, W. Demiaszkiewicz, and T. Sulgostowska. 1987. Abomasum nematodes in field and forest roe deer Capreolus capreolus (L.) over a yearly cycle. Acta Parasitologica Polonica 32: 339-348.

$\longrightarrow$, A. Malczewsi, $\longrightarrow$, and J. Lachowicz. 1997. The helminthofauna of farmed deer (Cervidae) in Poland. Acta Parasitologica 42: 225-229.

DunN, A. M. 1965. The gastro-intestinal helminths of wild ruminants in Britain. I. Roe deer, Capreolus capreolus capreolus. Parasitology 55: 739-745.

- 1983. Winter deaths in red deer: A preliminary report on abomasal parasite burdens. Publication of the Veterinary Deer Society 1: $17-25$.

Eve, J. H., AND F. E. KellogG. 1977. Management implications of abomasal parasites in southeastern white-tailed deer. Journal of Wildlife Management 41: 169-177.

Ferté, H., D. Cleve, J. Depaquit, S. Gobert, and N. Léger. 2000. Status and origin of Haemonchinae (Nematoda: Trichostrongylidae) in deer: A survey conducted in France from 1985-1998. Parasitology Research 86: 582-587.

García-Romero, C., F. Valcárcel, J. Corchero, A. S. Olmeda, and J. M. PÉREZ. 2000. Contribución al estudio de las parasitosis del ciervo (Cervus elaphus) en las provincias de Toledo y Ciudad Real (Castilla-La Mancha, España). Ecología 14: 235-249.

Govorka, I., L. P. Maklakova, I. Metukh, A. N. Pel'gunov, A. S. Rykovskit, M. K. Semenova, M. D. Sonin, B. ErkhardovaKOTRLÁ, AND V. IURASHEK. 1988. Gel'minty dikikh kopytnykh vostochnoi evropy. Akademiia Nauk SSSR, Moskva, Russia. 208 p.

Grenfell, B. T. 1992. Parasitism and the dynamics of ungulate grazing systems. American Naturalist 139: 907-929.

, K. Wilson, V. S. Isham, H. E. G. Boyd, and K. Dietz. 1995 Modelling patterns of parasite aggregation in natural populations: Trichostrongylid nematode-ruminant interactions as a case study. Parasitology 111: S135-S151.

Grossman, C. J. 1985. Interactions between the gonadal steroids and the immune system. Science 227: 257-261.

Halvorsen, O., and K. BYe. 1999. Parasites, biodiversity, and population dynamics in an ecosystem in the high arctic. Veterinary Parasitology 84: 205-227.

Hernández, S., F. Martínez, R. Calero, T. Moreno, and I. NavarRETE. 1980. Parásitos del ciervo (Cervus elaphus) en Córdoba. I. Primera relación. Revista Ibérica de Parasitología 40: 93-106.

HoberG, E. P. 1997. Parasite biodiversity and emerging pathogens: A role for systematics in limiting impacts on genetic resources. In Global genetic resources: Access, ownership and intellectual property rights, K. E. Hoagland and A. Y. Rossman (eds.). Association of Systematics Collections, Washington, D.C., p. 71-83.

- A. A. KoCAN, AND L. G. RicKARD. 2001. Gastrointestinal strongyles in wild ruminants. In Parasitic diseases of wild mammals, W. 
Samuel, M. Pybus, and A. A. Kocan (eds.). Iowa State University Press, Ames, Iowa, p. 193-227.

, S. J. Kutz, K. E. Galbreath, And J. CooK. 2003. Arctic biodiversity: From discovery to faunal baselines- revealing the history of a dynamic ecosystem. Journal of Parasitology 89: S84-S95.

, J. R. Lichtenfels, AND L. GibBOns. 2004. Phylogeny for species of the genus Haemonchus (Nematoda: Trichostrongyloidea): Consideration of their evolutionary history and global biogeography among Camelidae and Pecora (Artiodactyla). Journal of Parasitology. 90: 1085-1102.

- - AND P. A. PILiTT. 1993. Comparative morphology of Ostertagia mossi and Ostertagia dikmansi (Trichostrongylidae) from Odocoileus virginianus and comments on other Ostertagia spp. from the Cervidae. Systematic Parasitology 24: 111-127.

, K. J. Monsen, S. KuTs, AND M. S. Blouin. 1999. Structure, biodiversity, and historical biogeography of nematode faunas in holarctic ruminants: Morphological and molecular diagnoses for Teladorsagia boreoarcticus $\mathrm{n}$. sp. (Nematoda: Ostertagiinae), a dimorphic species in muskoxen (Ovibos moschatus). Journal of Parasitology 85: 910-934.

JANČEV, J. 1979. Helminths in the fallow deer (Dama dama L.) in the Voden and Krichim Hunting Preserves. Helminthologia 8: 64-82.

Kotrlá, B., AND A. Kotrlỳ. 1975. Development of the helminth fauna of the Dama dama in the Brezka game preserve. Acta Veterinaria Brno 44: 235-244.

Lancaster, M. B., and C. Hong. 1981. Polymorphism in nematodes. Systematic Parasitology 3: 29-31.

—, AND J. F. Michel. 1983. Polymorphism in the Trichostrongylidae. In Concepts in nematode systematics, special vol. 22, A. R. Stone, H. J. Platt, and L. Khalil (eds.). Academic Press, London, U.K., p. 293-302.

Lanfranchi, P., F. Tolari, R. Forletta, P. G. Meneguz, and L. Rossi. 1985. The red deer as reservoir of parasitic and infectious pathogens for cattle. Annali della Facultà di Medicina Veteterinaria di Torino 30: 83-97.

Lichtenfels, J. R., AND E. P. Hoberg. 1993. The systematics of nematodes that cause ostertagiasis in domestic and wild ruminants in North America: An update and a key to species. Veterinary Parasitology 46: 33-53.

- P. A. PilitT, And M. B. Lancaster. 1988. Cuticular ridge patterns of seven species of Ostertagiinae (Nematoda) parasitic in domestic ruminants. Proceedings of the Helminthological Society of Washington 55: 77-86.

Liegnel, V., J. CABARet, And J. F. Humbert. 2002. New molecular evidence that Teladorsagia circumcincta (Nematoda: Trichostrongylidea) is a species complex. Journal of Parasitology 88: 135140.

[MAFF] Ministry of Agriculture, Fisheries And Food. 1971. Manual of veterinary parasitological techniques. Her Majesty's Stationery Office, London, U. K., 131 p.

Margolis, L., G. W. Esch, J. C. Holmes, A. M. Kuris, and G. A. SCHAD. 1982. The use of ecological terms in parasitology (report of an ad hoc committee of the American Society of Parasitologists). Journal of Parasitology 68: 131-133.
Mason, P. 1994. Parasites of deer in New Zealand. New Zealand Journal of Zoology 21: 39-47.

Ortiz, J. M., M. Goyena, And F. D. Alonso. 1996. First report of two polymorphic species of Ostertagia (Nematoda: Trichostrongyloidea) in Cervus elaphus in Spain: O. leptospicularis and O. kolchida. Revista Ibérica de Parasitología 56: 221-223.

Poulin, R. 1996. Helminth growth in vertebrate hosts: Does host sex matter? International Journal for Parasitology 26: 1311-1315.

RehbeIN, S., AND W. HAupt. 1994. Infection of cattle, sheep and goat with gastrointestinal and lung nematodes from fallow deer during simultaneous grazing in a fallow deer farm. Deutsche Tierärztliche Wochenschrift 101: 456-460.

Rojo VÁzquez, F. A., AND M. Cordero del CAmpillo. 1975. Spiculopteragia spiculoptera (Guschanskaia, 1931) en Cervus elaphus L., en León. Anales de la Facultad de Veterinaria de León 21: 41-47.

Rossi, L., B. EcKel, AND E. Ferroglio. 1997. A survey of gastrointestinal nematodes of roe deer (Capreolus capreolus) in a mountain habitat. Parassitologia 39: 305-312.

Santín-Durán, M., J. M. Alunda, C. De la Fuente, and E. P. Hoberg. 2001. Onchocercosis in red deer (Cervus elaphus) from Spain. Journal of Parasitology 87: 1213-1215.

, C. De la Fuente, J. M. Alunda, B. M. Rosenthal, and E. P. HobERG. 2002. Identical ITS-1 and ITS-2 sequences suggest Spiculopteragia asymmetrica and Spiculopteragia quadrispiculata (Nematoda: Trichostrongylidae) constitute morphologically distinct variants of a single species. Journal of Parasitology 88: 417-418.

Soriguer, R. C., P. Fandos, E. Bernáldez, And J. R. Delibes. 1994 El ciervo en Andalucía. Editorial Consejería de Medio Ambiente. Junta de Andalucía, Sevilla, Spain.

Stevenson, L. A., R. B. Gasser, And N. B. Chilton. 1996. The ITS2 rDNA of Teladorsagia circumcincta, $T$. trifurcata and T. davtiani (Nematoda: Trichostrongylidae) indicates that these taxa are one species. International Journal for Parasitology 26: 1123-1126.

Suárez, V. H., M. R. Busetti, M. C. Fort, and D. O. Bedotti. 1991. Spiculopteragia spiculoptera, S. asymmetrica and Ostertagia leptospicularis from Cervus elaphus in La Pampa, Argentina. Veterinary Parasitology 40: 165-168.

, G. C. Mereb, R. M. Lorenzo, M. R. Busetti, And M. C. Fort. 1997. Parásitos internos hallados en ciervo colorado (Cervus elaphus L.) en la provincia de La Pampa (Argentina). Revista de Medicina Veterinaria 78: $77-80$.

Tellería, J. L., And C. SÁez-Royuela. 1984. The large mammals of Central Spain. An introductory view. Mammal Review 14: 51-56.

Zaffaroni, E., C. Citterio, M. Sala, and S. Lauzi. 1997. Impact of abomasal nematodes on roe deer and chamois body condition in an alpine environment. Parassitologia 39: 313-317.

, M. T. Manfredi, C. Citterio, M. Sala, G. Piccolo, and P. LANFRANCHI. 2000. Host specificity of abomasal nematodes in free ranging alpine ruminants. Veterinary Parasitology 90: 221-230.

Zarlenga, D. S., E. P. Hoberg, F. Stringfellow, and J. R. LichtenFELS. 1998. Comparisons of two polymorphic species of Ostertagia and phylogenetic relationships within the Ostertagiinae (Nematoda: Trichostrongyloidea) inferred from ribosomal DNA repeat and mitochondrial DNA sequences. Journal of Parasitology 84: 806-812.

ZuK, M., AND K. A. McKean. 1996. Sex differences in parasite infections: Patterns and processes. International Journal for Parasitology 26: $1009-1024$. 